\title{
Naratívne postupy v Belových Vedomostiach o Tekovskej stolici Jozef Kordoš
}

\author{
KORDOŠ, J.: The Narrative Techniques in Matthias Bel's Knowledge \\ of the Tekov County \\ SLOVENSKÁ LITERATÚRA 68, 2021, No. 1, p. 1-18 \\ DOI: https://doi.org/10.31577/slovlit.2021.68.1.1 \\ ORCID ID: 0000-0002-6853-459X
}

\begin{abstract}
Key words: Matthias Bel, Tekov
County, Jakob Tollius, Baroque

historiography, chorography
\end{abstract}

The goal of the paper is to characterize the narrative techniques that Matthias Bel (1684-1749) used in his paper Vedomosti o Tekovskej stolici (Knowledge of the Tekov County, 1742), usually considered to be a historiographic work. It tracks the passages where Bel's commentary overlaps with other genres or scientific branches, and draws attention to the elements that make it possible to classify the work as a chorography. Bel's aim was not only to systematically collect the accurate facts about the region but, apparently, also to saturate various needs of well-educated readership that finds pleasure in examining the picture of the region through a miscellaneous collection of natural particularities and specific cultural manifestations. Since the commentary on the Tekov county seeks support in quotations from the travelogue Letters from Travels (1700) written by the Dutch traveller Jakob Tollius (1633-1696), the reader explores the region as a traveller not only being accompanied by well-educated and sophisticated Bel, but also regularly through Tollius's gripping narrations. Another dominant element of the commentary is a number of etiologic legends, which Bel in the position of a collector of oral folk culture presents as an outstanding narrator. Comparison with other authors who also visited and described the region (F. E. Brückmann, E. Brown) shows that these digressions are a specific feature of Bel's picture of the Tekov county. 
elov výklad o Tekovskej stolici ${ }^{1}$ vyšiel spolu s opismi Novohradu, Nitry a Hontu vo štvrtom zväzku jeho rozsiahleho vlastivedného diela Notitia Hungariae novae historico geographica etc. v roku 1742, teda v poslednom zväzku Historicko-zemepisných vedomostí o novom Uhorsku, ktorý sa mu podarilo vydat' tlačou (Belius 1742; Bel 2019). V krátkom predslove (prooemium) k Tekovu, podobne ako v predslove $\mathrm{k}$ Hontu, sa Bel ospravedlňuje, že porušil vytýčený plán a ich poradie vo zväzku prehodil. Dôvodom na odsunutie výkladu o Honte až na záver zväzku bola skutočnost', že mu stále chýbali „podklady, o ktoré už tol'kokrát márne prosíkal" (Belius 1742:155). Aby nemárnil zbytočne čas čakaním a ani d'alej nezneužíval trpezlivost' cisárskeho veličenstva, prednostne do diela zaradil už finalizovaný Tekov. V predslove k Novohradu, ktorým sa štvrtý zväzok začína, však pomerne nesúrodo ${ }^{2}$ so skutočnostou a aj s tým, čo napísal v Ad lectorem, ${ }^{3}$ informuje čitatel'a, že obsah aktuálneho zväzku budú tvorit' opisy Novohradu, Hontu, Tekova, Nitry, Trenčína a aj Oravy. ${ }^{4}$ Pôvodne zamýšlané poradie sa teda nezmenilo len presunutím Tekova na druhé miesto, ale aj posunutím Nitry na tretie miesto.

1 Moderné vydanie a preklad celej Tekovskej stolice pozri Bel 2019.

2 Túto nesúrodost' možno vysvetlit' tak, že jednotlivé časti zväzku Bel neodoslal do tlače naraz. Ako prvý odovzdal a dal zrejme aj vytlačit Novohrad, pravdepodobne v čase, ked'opisy ostatných stolíc, ktoré plánoval do zväzku zaradit', ešte nemal hotové, a teda ešte nevedel, že celkovým rozsahom presiahnu možnosti jedného zväzku. Potom už akiste nemal na rukopis Novohradu dosah, inak by inkonzistentné informácie v predslove určite opravil. Uprednostnil Tekov, ktorý mal hotový a zjavne aj zrecenzovaný a finalizovaný pre tlač ešte za života cisára (ked'že hovorí, že nechce márnit čas veličenstva cisára, Augusti Caesaris, a nie cisárovnej), s vel'kou pravdepodobnostou aj skôr ako Nitriansku stolicu. Do textu o Tekovskej stolici však predsa len robil zásahy aj tesne pred jeho odovzdaním do tlače, ku ktorému mohlo dôjst najskôr v roku 1741. Vyplýva to zo spol'ahlivo datovatel'ného údaja v časti venovanej dejinám Kremnice, kde Bel v súvislosti s banskoštiavnickým komorským grófom Jozefom Andrejom Wenczlom, barónom zo Sternbachu, ktorý zomrel v roku 1736, píše, že „pred piatimi rokmi predčasne opustil tento svet“ (Kianička 2018: 39). Úvod Ad lectorem napísal až úplne nakoniec, preto sa v ňom už udávajú správne informácie o obsahu aktuálneho zväzku aj o poradí jeho jednotlivých častí. Hoci rukopisy Trenčianskej a Oravskej stolice čakali na finálnu redakciu a vydanie, Bel nepovažoval za ukončenú ani prácu na nich, naopak, najnovšie zistenia a informácie do nich zapracúval a dopĺňal ešte aj v štyridsiatych rokoch 18 . storočia (Nagy 2013: 31).

3 Bel v úvode Ad lectorem informuje, že pristúpil k zmene pôvodného konceptu Vedomostí, ktorá sa dotkla nielen poradia opisov jednotlivých stolíc, ale aj ich počtu. V \$ XII Ad lectorem udáva, že štvrtý zväzok obsahuje opisy štyroch stolíc Preddunajského dištriktu, konkrétne Novohradskej, Tekovskej, Nitrianskej a „oboch Hontov“, pričom nezabúda podotknút, že opis Hontianskej stolice mal byt' pôvodne na druhom mieste. Pôvodný zámer pripojit' k nim aj opisy Trenčianskej a Oravskej stolice znemožnila skutočnost', že zväzok „,celkom nečakane nabral na rozsahu“. To Bela prinútilo zmenit pôvodný plán a presunút oba výklady až do šiesteho zväzku. V $\$$ XIII potom uvádza, že k dokončeniu celého projektu zostáva vydat' už len tri budúce zväzky, v ktorých zamýšla prezentovat' opisy zvyšných tridsiatich ôsmich uhorských stolíc. Z toho tiež vyplýva, že sedemzväzkové Vedomosti Bel zamýšlal už pred koncom roku 1741, ked'že svoje Ad lectorem datoval „MDCCXLI. III. Idus Decembr.“, teda na 11. decembra 1741. Podla I. Kollárovej došlo k tejto zmene niekedy po slávnostnom odovzdaní štvrtého zväzku Márii Terézii v roku 1742 (Kollárová 2006: 37).

4 „Scilicet Comitatus sunt vasti et elegantes, sed alter commodior altero: Neogradiensis, Hontensis, Barschiensis, Nitriensis, Trentschiniensis atque Arvensis. Volumen hi dabunt iustae molis neque prioribus seu rerum habitu, seu adparatibus aliis impar. Exordimur autem designationis eum laborem a Neogradiensium provincia, dum per intersitos Comitatus ad Arvenses delati tomo huic juxta et Parti Primae sive Hungariae Cis-Danubianae finem constituamus“ (Belius 1742: 2). Z toho je zrejmé, že úvod Ad lectorem aj všetky predslovy $\mathrm{k}$ jednotlivým stoliciam predstavujú dôležité paratexty, ktoré zásadným spôsobom osvetlujú okolnosti vzniku a vydania štvrtého zväzku Vedomostí. Bližšie o paratextoch a autorských predhovoroch Karabová 2018. 
Tekovská stolica zaberá vo štvrtom zväzku strany 155-290. Výklad má v zásade rovnakú štruktúru ako všetky ostatné a riadi sa obvyklým postupom, ktorý Bel zaviedol predstavením modelového opisu Spišskej stolice vo svojom spise Hungariae Antiquae et Novae Prodromus (skrátene Prodromus, Posol starého a nového Uhorska) z roku 1723 (Belius 1723). ${ }^{5}$ Opis Tekovskej stolice má v pôvodnom vydaní 135 strán, z nich prvá, všeobecná čast' má rozsah 23 strán, zvyšných 112 strán vyhradil autor špeciálnej časti. Ked'že Tekovskú stolicu tvorili štyri slúžnovské okresy, špeciálna čast' sa delí na štyri oddiely, z ktorých prvý obsahuje opis Oslianskeho slúžnovského okresu (Processus Oszlanensis, strany 179-242), druhý Levického (Processus Lévensis, strany 243-264), tretí Topol'čianskeho (Processus Kis-Topoltschanensis, strany 265-282) a napokon štvrtý Vrábel'skej stolice arcibiskupských predialistov ${ }^{6}$ a Vrábel'ského slúžnovského okresu (Sedes et Processus Verebélyensis, strany 283-290). Aj opis Tekova Bel uzatvára prehl'adom cestných komunikácií do susedných stolíc (strany 290-291).

\section{Na ceste Tekovom s Jakobom Tolliom}

Zachovanie jednotnej štruktúry a dodržiavanie zaužívaného postupu pri opise jednotlivých stolíc však nijako neprekáža Belovi v tom, aby o svojom výklade rozprával ako o ceste (iter) po jednotlivých uhorských krajoch. O tom, že Bel svoje rozprávanie ako cestu mohol koncipovat', svedčí okrem prítomnosti slova iter hned' v krátkom predslove aj fakt, že pokial'ide o priznané zdroje, svoj výklad často a aj s neskrývaným potešením opiera o kratšie i rozsiahlejšie citáty z cestopisu Epistolae itinerariae (Listy z ciest) Jakoba Tollia, vzdelaného nizozemského cestovatel'a, lekára a vynikajúceho filológa. 7 Prvý raz ho Bel cituje hned'v $\$$ II úvodného oddielu všeobecnej časti o prírodných pomeroch kraja, ked' sa venuje horám medzi Kremnicou a Banskou Bystricou a na oživenie svojho rozprávania využiva Tolliov opis jeho cesty cez ne. Tolliova cesta po uhorských, resp. slovenských banských mestách, ktorú opisuje $\mathrm{v}$ piatom liste $\mathrm{z}$ ciest, pochopitel'ne nemala rovnaký priebeh ani smer, akým postupuje Belov výklad. Rozmenit' na drobné pútavé rozprávanie nizozemského vzdelanca, ktoré obsahuje množstvo bystrých pozorovaní a cenných informácií, a zaradit ich na príslušné miesto vlastnej cesty po Tekove vtedy, ked'k nemu výklad dospeje, nepredstavovalo pre Bela zaiste žiaden problém a porovnanie s Tolliovou pôvodinou ukazuje, že Bel jeho text vel'mi dobre poznal a využival ho naozaj efektívne a dôkladne.

Nie je to len na spestrenie výkladu. Bel siaha po citáte z Tolliovho cestopisu tiež $\mathrm{v}$ prírodovednom oddiele, ked' informuje o vodstvách regiónu, konkrétne o Kremnickom potoku. Tu sa už neobmedzuje len na jednoduché pozorovanie cestovatela, že potok je špinavý a kalný, pretože preteká viacerými stupami

5 K problematike porovnaj napr. Tibenský 1984: 217-227 alebo Juríková 2016: 17.

6 K problematike stolice arcibiskupských predialistov porov. Oslanský 1986; Lopatková 2009.

7 Jakob Tollius (1633 - 1696) napísal o svojich cestách cestopis vo forme listov, z ktorých každý niekomu adresoval, je ich dovedna šest' a vyšli knižne pod názvom Listy z ciest v Amsterdame v roku 1700 až po autorovej smrti (Tollius 1700). Jeho podrobný životopis uvádza Koldewey 1894. Najbližším zdrojom informácií o Tolliovi, jeho diele a živote je však predovšetkým Prologus ad lectores, ktorý napísal vydavatel' Tolliových listov H. Ch. Heninnius a vydal v úvode Epistolae itinerariae. 
a banskými dielami, ale dáva priestor aj jeho názorom a zdôvodneniam pozorovaných javov. Podl'a Tollia je totiž Kremnický potok jednoznačne zlatonosný a odnáša zo stúp dokonca vel'kú väčšinu vydolovaného zlata, pretože spôsob premývania rozdrvenej rudy je nadmieru neefektívny. Tollius ho opísal na inom mieste, ale Bel s potešením pripája k tomuto miestu aj d'alší citát, čím výklad o Kremnickom potoku, ktorý by mal byt' na tomto mieste prírodovedný, rozširuje aj o technické údaje, ako sa premýva zlatá ruda po rozdrvení v stupách a ako pri tom podla Tolliovho názoru dochádza k obrovským stratám (Belius 1742: 163).

Ešte v prírodovednom oddiele, vo výklade o podivuhodných a liečivých vodách regiónu, Bel opät' uvádza pomerne rozsiahly citát z Tollia. Cestovatel'tentoraz opisuje svoju návštevu kúpel'ov v Sklených Tepliciach a rozplýva sa v typicky barokovom vyumelkovanom opise nad krásami a zaujímavými prírodnými úkazmi, ktoré videl v kúpel'nej jaskyni. Odborný opis kúpel'ov a tamojších minerálnych vôd Bel uverejnil už v Prodrome. ${ }^{8}$ Na tomto mieste teda okrem odkazu naň a poznámky, že kúpele majú už ovel'a honosnejší vzhl'ad, prináša Tolliov takmer básnický opis, ktorý zaiste pôsobí ako príjemná zmena a osvieženie v inak pomerne suchopárnom výpočte minerálnych a termálnych prameňov kraja (Belius 1742: 165).

V druhom oddiele prvej, všeobecnej časti, ktorý sa venuje obyvatel'stvu kraja a jeho zloženiu, úradom, významným rodom a d'alším obvyklým spoločenskovedným otázkam, sa zakladá na citátoch z Tollia prakticky celá charakteristika obyvatel'stva regiónu. Už $₫$ II takmer celý vypíňa citát, v ktorom Tollius referuje o troch národnostiach obyvatel'stva a zároveň prináša svoj vlastný a z odstupu času vel'mi cenný opis ich typického vzhl'adu a spôsobu odievania. Pomerne detailne sa venuje ženskému ludovému odevu, ktorý mali v Tekove iný slobodné dievčatá a iný vydaté ženy. Bel v Tolliovom opise v podstate sprostredkúva dosial'najstarší známy opis tekovského kroja. ${ }^{9}$

Rovnako $₫$ III je z väčšej časti tvorený citátmi z Tollia. Tollius okrem toho, že obdivuje odolnost' tunajších Slovákov a pripisuje ju skutočnosti, že sú od útleho detstva vystavovaní tvrdosti poveternostných vplyvov, referuje aj o celkom ojedinelom spôsobe, akým si tunajšie obyvatel'stvo prepravuje proviant, ked'sa vydáva na cesty. Ide o špeciálny druh kapsy, aký podla Tollia „nepoznal ani kynik Diogenés", 10 ked'že bežní ludia si odkladali jedlo na cestu do spodnej bielizne. Bel upresňuje, že je to typické pre Slovákov, ktorí si v lete spodnú bielizeň zvyknú vyhrnút nad kolená a chlieb, syr, cesnak a cibulu si odkladajú do nej. Mad'ari na rozdiel od nich zvyknú na to používat zviazané rukávy cestovného plášta, ktorý

8 Výklad v Prodrome je, samozrejme, ovela rozsiahlejší, delí sa na tri časti (membrum historicum, membrum physicum, membrum medicum) a vychádza z dostupných súvekých odborných zdrojov, ako je napríklad základná práca na túto tému De admirandis Hungariae aquis od Juraja Wernera alebo cestopis vynikajúceho anglického lekára Edwarda Browna A briefaccount of some travels in Hungaria, Servia, Bulgaria, Macedonia, Thessaly, Austria, Styria, Carinthia, Carniola, and Friuli etc. (Londýn 1673). Treba však povedat', že aj tu sa pomerne často cituje Tollius a v časti venovanej kúpel'nej jaskyni sa doslovne prepisuje to isté miesto, ktoré Bel cituje v prírodovede Tekovskej stolice (Belius 1723:128-139; Tolliov opis potnej jaskyne na strane 132). 9 Moderné opisy vychádzajú poväčšine $\mathrm{z}$ údajov z konca 19., prípadne zo začiatku 20. storočia. O tekovskom kroji podrobnejšie Nosál'ová 1983: 75-81; Kucbel'ová - Brenkus 2018: 248-261.

10 Tollius prostredníctvom narážky na Diogena vel'mi učene a jemne naznačuje, že takéto využitie spodnej bielizne je pre človeka vyberaných (mestských) spôsobov príliš daleko za hranicami únosnosti. 
sa volá csuha. Výklad d'alej pokračuje novým citátom, v ktorom Tollius hovorí o tzv. sympatizujúcich účinkoch potu, a tvrdí, že jedlo, ktoré sa takýmto spôsobom prepravuje, nasiakne potom a ten práve prostredníctvom svojho sympatizujúceho účinku vyvolá lásku v človeku alebo zvierati, ktoré takéto jedlo požije. Práve táto viera ho viedla $\mathrm{k}$ tomu, aby takýto pokrm radšej slušne odmietol. Pre aktuálnu interpetáciu je však dôležitejšie to, že sa vzápätí priznáva, že v prípade iných miestnych špecialít taký zdržanlivý nebol. Išlo konkrétne o jedlá nakladané $\mathrm{v}$ cesnaku a Bel skutočne pokračuje d'alej $₫$ IV, ktorý sa venuje len použitiu a konzumácii cesnaku ako špecifika miestneho stravovania.

\section{Cesnak, typické jedlo Uhrov}

V úvode paragrafu nadväzuje najprv na Tolliovu poznámku, že od konzumácie miestnych delikates nakladaných $\mathrm{v}$ cesnaku ho neodradila ani tažká aróma, na ktorú má jednoducho príliš mestský žalúdok, ani Horatiove verše, podla ktorých je cesnak horším jedom než bolehlav. Bel v úvode cituje in extenso príslušnú Horatiovu báseň, ${ }^{11}$ aby jeho kritiku vzápätí vyvrátil tak, že uvádza celý rad zmienok o cesnaku a jeho použití u najrôznejších autorov od klasického staroveku až do svojich čias. Sú medzi nimi Plínius Starší, Aemilius Macer, Athénaios či Erazmus Rotterdamský, z autorov najbližších Belovej dobe je to predovšetkým Tobias Kober, ${ }^{12}$ pol'ný lekár v armáde Rudolfa II., ktorého Bel necituje na tomto mieste prvý raz. Prostredníctvom výňatku z jeho Observationes medicae castrenses Hungaricae (Lekárske táborové pozorovania v Uhorsku) informuje čitatel'a o množstve využitia cesnaku na lekárske účely, ktoré lekár počas svojho pôsobenia v Uhorsku odpozoroval. Belov paragraf o cesnaku sa svojím obsahom, pokial' ide o zmienky antických autorov, v zásade nijako nelíši napríklad od hesla Allium (cesnak) $\mathrm{v}$ dobovej encyklopédii rímskej antiky, v slovníku Lexicon antiquitatum Romanarum (Pitiscus 1719: 73). Bel ten istý materiál vo svojom paragrafe vlastne len preusporiadal, zmienky niektorých autorov vynechal (predovšetkým básnikov, ako napr. Iuvenala, Persia či Nonna) a nahradil ich Koberovým výkladom, prostredníctvom ktorého prepojil antickú tradíciu s domácim prostredím. Uhorský zvyk konzumovat' cesnak a využívat' ho ako liek (napr. proti tzv. uhorskej nevolnos$t i$, ludovo zvanej csömör, pri ktorej treba cesnakom pretlačeným do octu potierat'

11 Q. Horatius Flaccus, Epodon Liber, Carmen III.

12 Tobias Kober (okolo 1572 - po 1612) bol lekár a dramatik z Görlitzu. V letnom semestri roku 1593 bol imatrikulovaný v Lipsku, v roku 1594 tam študoval už ako poeta laureatus medicínu. Už v roku 1593 spísal lekársky traktát De lacte a v roku 1595 na základe dizertácie De paralysi promoval v Helmstädte na doktora medicíny. Následne sa stal pol'ným lekárom pri armáde cisára Rudolfa II. v Uhorsku, v roku 1605 vydal prácu Decades tres observationum medicarum castrensium Hungaricarum, ktorá obsahuje zaujímavé historické informácie o epidémiách a nákazách tej doby a z ktorej cituje aj Bel. Okrem odborných spisov sa Kober venoval aj poézii a dráme - už v roku 1593 napísal oslavnú báseň na Vroclav (Vratislavia sive Budorgis, celebris Elysiorum Metropolis), z piatej knihy Aeneidy čerpal látku pre drámu Palinurus (Ludi Funebres Sive Palinurus. Tragoedia Ex Quinto libro Aeneidos Virgilianae. Leipzig 1593), z tretej pre drámu Anchises Exul (Anchises Exul tragoedia ex III. Libro Aeneidos Virgilianae Ad Dominum Sebastianum Willingium Onoldium..., Gorlicii/Görlitz 1594). Celkove bol autorom viacerých latinských drám (komédií i tragédii), jednej nemeckej. Bližšie Scherer 1882: 359-360. 
postihnutému končatiny) ${ }^{13}$ má teda v jeho podaní antické korene siahajúce až do starého Egypta a predstavuje prastarý kultúrny prvok, ktorý existuje dodnes v tekovskom zvyku pohostit príchodzích pri vstupe do domu chlebom a cesnakom. $\mathrm{V}$ tomto konkrétnom prípade, ako sa uvádza v záverečnom odseku $₫ I V$, hovorí Bel z vlastnej skúsenosti, ked'že na cestách mu pri vstupe do vidieckych pohostinstiev ako prvé uvítanie bežne ponúkli chlieb, cesnak a cibul'u.

Treba však pripomenút', že Tollius a Kober neboli jediní lekári a vzdelaní cestovatelia, ktorí zaregistrovali všestranné použitie cesnaku v Uhorsku ako špecifický a zároveň nanajvýš charakteristický prvok národnej kultúry. Možno medzi nich určite rátat' aj vzdelaného lekára, polyhistora a cestovatel'a Franza Ernsta Brückmanna (1696-1754), ${ }^{14}$ ktorý svoju cestu po hornom Uhorsku, teda dnešnom Slovensku, podnikol v roku 1724 a následne o nej obsiahlo referoval v sérii cestopisných listov adresovaných svojim priatel'om. Stojí určite za zmienku, že posledný z týchto listov s poradovým číslom sto, ktorý vyšiel v roku 1741, venoval, resp. adresoval Matejovi Belovi. ${ }^{15}$ Brückmann sa živo zaujímal o prírodné pomery Slovenska a vyspelé baníctvo (Hronček 2019: 25-26) či kultúru a život obyvatel'ov Horného Uhorska, preto nie je nijakým prekvapením, že väčšina tém, ktoré vo svojich cestopisných listoch spracúva, sa objavuje aj v Belových Vedomostiach (hory a dračie jaskyne Liptova, minerálne a liečivé pramene, kremnické a banskoštiavnické zlato a striebro, špecifiká fauny a flóry a d'alšie). Okrem Listov z ciest, ktoré nazval rovnako ako Tollius Epistolae itinerariae, publikoval aj obdivuhodné množstvo kratších či dlhších správ (Relationes itinerariae) v súvekom periodiku Annalium Physico-Medicarum, oder Geschichte der Natur und Kunst, medzi nimi aj správu Von den ungarischen Zwiebeln und Knoblauch (Anno MDCCXXV, Augustus, relatio $X X X I I) .{ }^{16}$ Brückmann v nej referuje, že v Uhorsku sa cibula a cesnak konzumujú bud' surové, alebo varené pred, počas i po jedle, sú preto pre Uhrov najlepším aroma domesticum (domácim korením) a vedno s vínom sa považujú za všeliek. Uhri preto zriedka niečo potrebujú z lekárne a vel'mi ojedinele volajú lekára, ked'že v prípade nevol'nosti ako prvú pomoc podávajú cibulu, cesnak a „dobrý pohár vína“ a lekára volajú až vtedy, ked' sa želaný účinok nedostavuje (čo je zväčša príliš neskoro, ako podotýka autor). Každodenná konzumácia cesnaku

13 „Aj dnes je liekom proti uhorskej nevol'nosti, ktorú označuje domáci výraz csömör, nielen u ludu, ale aj medzi vznešenejšími. Pretlačený do octu sa s nadmieru znamenitým úspechom starostlivo rozotiera na končatiny. Tým, ktorí sa takto raz a aj druhý raz potrú, sa napokon obnovia stratené sily v celom tele, spamätajú sa zo zmeravenia, ktorým sa táto choroba typicky prejavuje, a ked' sa im konečne vráti chut' do jedla, vrátia sa k svojej práci svieži a dobre naladeni““ (Belius 1742: 174).

14 O jeho živote porovnaj Zaunick 1955: 655.

15 FRANC. ERNEST. BRÜCKMANNI D. EPISTOLA ITINERARIA C. SISTENS SCRIPTORES RERUM HUNGARICARUM. AD VIRUM REVERENDISSIMUM, DOMINUM DOMINUM MATTHIAM BELIUM, PANNONIUM, VERBI DIVINI ET EVANGELICI IN ECCLESIA GERMANICA POSONIENSI MINISTRUM VIGILANTISSIMUM, POLYHISTOREM CONSUMATISSIMUM, CELEBERRIMUM, AMICUM ET FAUTOREM OMNI HONORIS ET AMORIS CULTU NUNQUAM NON MAXIME VENERANDUM. WOLFFENBUTTELAE, 1741 (Brückmann 1741). Porovnaj tiež Šimončič 1998: 250.

16 Časopis vychádzal s mesačnou periodicitou a vydávali ho po kvartáloch ako Sammlung, konkrétne táto správa vyšla v Sammlung von Natur- und Medicin wie auch hierzu gehörigen Kunst- und Literatur-Geschichten, so sich An. 1725 in den 3. Sommer-Monaten in Schlesien und andern Ländern begeben. Als der drey u. dreyssigste Versuch ans Licht gestellet von Einigen Academ. Naturae Curios. in Bresslau. Sommer-Quartal, 1725. Leipzig und Budissin, Verlegts David Richter, 1727, strana 194. Úctyhodnú Brückmannovu bibliografiu uvádza Meusel 1802: 613-623. 
a cibule chráni Uhrov proti vel'kému množstvu chorôb (okrem iných aj pred obličkovými a žlčníkovými kameňmi, podagrou a artritídou), jeho tažká aróma však spôsobuje na druhej strane aj to, že ich často sužujú bolesti hlavy. Na ilustráciu, čo cesnak a cibul'a pre Uhrov znamenajú, uvádza Brückmann citát od d'alšieho slávneho nemeckého polyhistora a cestovatel'a, Martina Zeilera $(1589-1661),{ }^{17}$ ktorý vo svojom diele Descriptio Hungariae oder die Beschreibung des Königreichs Ungarn (Ulm, 1646) tvrdí, že Uhri konzumujú cesnak s rovnakou chutou a so zápalom ako Španieli red'kev. Bel, ked'že bol eruditione Germanus, nepochybne poznal tento obraz Uhorska v zahraničnej geografickej a cestopisnej literatúre, ale tým, že špeciálny výklad o cesnaku umiestňuje do spoločenskovedného oddielu svojho opisu Tekovskej stolice a poukazuje na živý zvyk vítania príchodzích cesnakom a cibul'ou, predstavuje vzdelanému svetu práve Tekov ako región, ktorý svojou živou tradíciou prispieva k národnej kultúre Uhorského král'ovstva jedným z jej zásadných identifikujúcich prvkov.

\section{Dejiny slobodných král'ovských banských miest}

Po všeobecnej časti, ktorú v jej druhom oddiele uzatvára niekol'ko obvyklých paragrafov venovaných typickým zamestnaniam obyvatel'stva (hlavne kremnického), stručným charakteristikám jednotlivých panstiev stolice, urodzeným rodom a stoličným úradom, pokračuje Belova cesta Tekovom ovel'a rozsiahlejšou špeciálnou častou. V súlade so zaužívaným postupom ju Bel začína výkladom dejín slobodných král'ovských miest Oslianskeho slúžnovského okresu, kde sa ako v jedinom z okresov Tekova nachádzali slobodné král'ovské mestá, konkrétne dve a obe navyše banské. Prvé sú dejiny Kremnice, druhé Novej Bane.

Dejiny dôležitejšej a významnejšej Kremnice sú v porovnaní s dejinami Novej Bane značne rozsiahlejším výkladom a rozsahom tridsatosem strán v pôvodnom vydaní predstavujú aj podstatnú čast' celého opisu Tekovskej stolice. V dvadsiatich piatich paragrafoch Bel spracúva postupne históriu mesta od najstarších čias, prezentuje vlastnú etymológiu mena Kremnica, prostredníctvom ktorej sa pokúša viac-menej objasnit aj počiatky mesta, vykladá o panovníkoch, s ktorými sa počiatky mesta spájajú, a zameriava sa pritom aj na začiatky a rozvoj baníctva a tažby zlata. Po opise polohy a vzhl'adu mesta, jeho brán, hradieb, cirkevných a svetských stavieb sa práve v súvislosti s výkladom o niektorých cirkulárnych domoch dostáva k dôležitým informáciám o špecifických inštitúciách, ktoré v meste sídlia, ako napr. arcibiskupský pizetár, cisársko-král'ovská komora a mincovňa. V $₫ I X-X I I$ Bel analyzuje pôvod kremnickej komory, jej podobu, úrad komorského grófa a prináša jedinečný pohlad na ostatných banských úradníkov a ich charakteristiku. Komorská správa prešla v roku 1748 reformou a jediná podrobnejšia správa, ktorá sa zachovala o jej stave pred týmto rokom, je Belov súpis (Kianička 2018:

17 Tu treba podotknút, že Bel Zeilerovo dielo poznal, ked'že v Prodrome ho viac ráz citoval vo výklade o kúpel'och v Sklenom, konkrétne s odkazom na diela Topographia Galliae a Topographia Germaniae (Belius 1723: 131). Bel uvádza okrem Tolliovho opisu kúpel'nej jaskyne aj vlastné pozorovania a hoci kúpele v Sklenom opísal aj Brückmann v 75. liste z roku 1738 (Brückmann 1738: 2-3), Bel sa pri zmienke o kúpel'och v prírodovednej časti Tekovskej stolice uspokojuje len s tým, že zopakuje Tolliov opis a pridá k nemu poznámku, že „vzhl'ad potnej jaskyne a kúpel'ov je už ovel'a vznešenejší, než bol za Tolliových čias“ (Belius 1742: 165). Na žiadny modernejší opis než svoj z roku 1723 však neodkazuje. 
183). Bel ním vlastne zaviedol latinskú nomenklatúru jednotlivých úradov tak, že ich pôvodne nemecké pomenovania, ktoré, samozrejme, uvádza tiež, preložil do latinčiny. Pri tom sa usiloval prostredníctvom latinského termínu vždy vystihnút podstatu pracovnej náplne príslušného úradníka. Treba však povedat', že Bel nebol úplne prvý, kto pre svoje dielo vytvoril vlastnú latinskú nomenklatúru jednotlivých banských úradov. Predchádzal mu Jakob Tollius, ktorého piaty list Bel s oblubou a na mnohých miestach cituje aj v prípade dejín Kremnice. Pokial'ide o latinské pomenovania banských a komorských úradníkov, Bel nevychádzal zo svojho predchodcu, hoci ich určite poznal a v prípade hospodára zásob (Zeüg-schreiber, čo Bel prekladá promus condus) nezabúda vzdelaného cestovatel'a spomenút' a pochválit' za to, že názov tohto úradu vel'mi výstižne preložil do latinčiny výrazom neccessariorum praebitor, teda poskytovatel' potrieb. Tolliovým zámerom však, pravda, nebolo poskytnút na danom mieste svojho cestopisu dôsledný opis kremnických komorských úradov, ich náplne práce či právomocí, ale zvečnit'vo svojom diele mená tých úradníkov, s ktorými sa počas svojho pobytu v Kremnici stretol a vyjadrit' im tak vd'aku za ich priatel'skú pohostinnost', ochotu a ústretovost' (Tollius 1700: 183).

Jediná téma, ku ktorej sa Bel v dejinách Kremnice vracia dva razy a vždy jej venuje samostatný paragraf (prvý raz $₫$ VIII, druhý raz $\$ X X I V)$, sú udalosti, ku ktorým došlo v Kremnici z jeho pohl'adu nedávno počas krátkeho panstva rákociovcov. Prináša tu charakteristiku „ludí tej doby“ a postoj, ktorý Bel k rákociovcom zaujíma, je naozaj nekompromisný a celkom v súlade s politickým konceptom viedenského dvora. Nejde tu len o referovanie o povstaní prostredníctvom politicky korektných slov (tumultus, seditio) či vylúčenia výrazu bellum (Kollárová 2006: 39; Nagy 2015: 46; Kianička 2018: 30-31), ktoré sa mimochodom aj tak vyskytuje v ôsmom paragrafe v súvislosti s povstaním, ked' ho Bel nazýva ,celkom nespravodlivou vojnou" (iniquissimum bellum) (Belius 1742: 191). Ide predovšetkým o ostrú kritiku mravných pokleskov čelných predstavitel'ov povstania, hlavne Mikuláša Berčéniho. Hoci pri vodcovi povstania Rákocim prejavuje Bel istú zhovievavost', možno i súcit, ${ }^{18}$ Berčéniho tvrdo prenasleduje aj na iných miestach Vedomostí (Nagy 2017: 28) a v dejinách Kremnice ho neváha vykreslit' ako najpažravejšiu z (rákociovských) harpyí, ktorá striehne na kremnické zlato a striebro niekde v jaskyni, raz v Bojniciach, inokedy v Banskej Bystrici. Na jeho lúpenie má vždy pohotovo „oči Arga, ruky Briarea a pazúre sfing“ (Belius 1742: 192, poznámka a). Mikuláša Berčéniho teda zobrazuje ako kombináciu viacerých mytologických príšer, démonickej harpye s telom vtáka a tvárou ženy, stookého a nikdy nespiaceho strážcu Arga, storukého obra Briarea a sfingy.

Ked' sa Bel k zločinom rákociovcov vracia druhý raz v $\mathbb{X X I V}$, hovorí o Kremnici počas ich panstva ako o „dielni zla“ (officina malorum). Kremnica sa ňou stala na celých pät rokov, počas ktorých sa v nej razili medené mince a zlato a striebro sa celkom bezočivo rozkrádalo. Hoci sa na rákociovských minciach skvel nápis Za slobodu, po porážke sa podl'a Bela čelní predstavitelia povstania

18 Bel v poznámke $\mathrm{z} \mathrm{k}$ danému miestu upozorňuje, že jediný $\mathrm{z}$ popredných predstavitelov povstania, kto sa zdržal tohto zločinu, bol sám vodca, preto aj napokon odišiel do vyhnanstva ako najväčši chudák (pauperrimus). 
nestarali o nič iné, len aby sa nakradnuté zlato a striebro nedostalo do rúk nepriatel'ov, a ušli na juh do tureckého azylu (Belius 1742: 215). Bel sa tu nepúšta do otvoreného moralizovania a prezentovania pomerne prísnych morálnych zásad pietizmu, ${ }^{19}$ ked'že Vedomosti na to zaiste neponúkali najvhodnejšie fórum, ${ }^{20}$ ale radšej siaha po menej otvorenom, ale možno o to účinnejšom a univerzálnejšom spôsobe pranierovania mravnej spustnutosti rákociovcov. Využíva na to citát z listu C. Sidonia Apollinara jeho priatelovi Thaumastovi, v ktorom sa tento vynikajúci neskoroantický básnik a arvernský biskup stažuje na úbohé mravy galských provinciálov, svojich krajanov. ${ }^{21}$ Ako svedčí množstvo odkazov na poznámky pod čiarou, Bel si dal skutočne záležat' na tom, aby v rozsiahlom poznámkovom aparáte, ktorý k miestu pripojil, dôkladne vysvetlil čitatel'ovi, v akom význame sa každé meno používa, čo znamená a ako ho použili iní autori, predovšetkým poprední básnici ako Vergilius, Ovidius, Homér a d'alší. Pomerne často pritom cituje Vergilia a nepredstavuje preňho nijaký konfesionálny problém odporučit' svojmu čitatel'ovi komentár francúzskeho jezuitu de La Rueho ${ }^{22} \mathrm{k}$ Vergiliovi. Opakovaná kritika mravných pokleskov rákociovcov tak pôsobí ako jedna z hlavných tém výkladu dejín Kremnice. Práve jej prostredníctvom autor prináša viacero vlastných evaluácií niektorých elít súvekej spoločnosti, z ktorých sa čitatel'má možnost'poučit' nielen o všeobecne platných mravných ideáloch, ale aj o určitých konštantách ludského správania a o tom, ako to zvykne skončit', ak sa do vedúcich pozícií presadia ludia so slabostou pre moc a bohatstvo.

Rovnako silný moralizujúci náboj ${ }^{23}$ má aj podanie dejín druhého slobodného král'ovského a banského mesta v Oslianskom slúžnovskom okrese. Dejiny Novej Bane (Historia Regiomonti) sú však v porovnaní s dejinami Kremnice ovela stručnejšie. Na ich spracovanie Belovi postačilo sedem paragrafov na ôsmich stranách pôvodného vydania, zjavne teda nemal $k$ dispozícii podobne bohaté zdroje informácií či staršie spracovania dejín mesta ako v prípade Kremnice, ktorú viac razy navštívil, poznal ju z vlastnej skúsenosti a mal v nej viacero priatel'ov a dobrých kontaktov (Kianička 2018: 40-42). Jadro výkladu tvoria preto dve rozprávania, resp. dve Belove spracovania ústnych podaní. Náklonnost' král'ovnej Márie (1371 -1395) k mestu predstavuje pre Bela vlastne jedinú istú informáciu, ktorú môže

19 O Belovi ako poprednom predstavitel'ovi uhorského pietizmu porov. Gluchman 2017: 139-152.

20 Dotýkat sa podobných tém a vážnejších náboženských otázok nebolo v súlade s politickým konceptom viedenského dvora a na to, aby sa podobné témy v texte neobjavovali, dozerala pomerne prísna cenzúra dvorskej kancelárie (Kollárová 2006: 39).

21 „Stále nádeje vkladajú do prevratov, istoty nachádzajú v neistých časoch a trasú sa vo vedomí vlastnej zbabelosti, ked' sú z nich levy vo velitel'ských stanoch, v táboroch sa zas ako zajace boja dohôd, aby sa neporušili, bitiek, že sa zvedú, a ked' raz zavoňajú odniekial' pach hrdzavočerveného mešca, okamžite tam upriamia Argove oči (n.), načahujú ruky Briarea a pazúry sfíng (o.), sú vierolomní ako Laomedón (p.), prefíkaní ako Odyseus, klamú ako Sinon (q.) a verit im možno ako Polymnestórovi (r.), zbožní sú ako Pygmalión (s.)“ (Belius 1742: 215, 216); malé písmená v zátvorkách sú odkazy na Belove poznámky pod čiarou, ktoré k tomuto miestu pripojil ako vysvetlivky.

22 Charles de La Rue SJ, po latinsky Carolus Ruaeus (1643 - 1725), francúzsky jezuitský kazatel', autor viacerých drám, básní a komentovaného vydania Vergilia, na ktoré odkazuje aj M. Bel (P. Virgilii Maronis Opera interpretatione et notis illustravit Carolus Ruaeus Soc. Iesu... ad usum Serenissimi Delphini. Editio Secunda. Parisii: Apud Simonem Benard, Ex Typographia Dionysii Thierry, 1682) (Champon 1910).

23 Špeciálne o tomto aspekte Belovho výkladu dejín niektorých miest porovnaj Kordoš 2019. 

prečo sa chotár Novej Bane rozprestiera predovšetkým na pravom brehu Hrona. Ked'že mesto malo priúzky chotár, král'ovná dala meštanom možnost' rozšírit' ho tak, že mesto si doň mohlo pripísat' všetko, čo dokážu zememerači prejst' za jeden deň. Meštania na to vybrali štyroch s najlepšími nohami, ktorí mali územie mesta rozšírit počas najdlhšieho dňa v roku. Dvaja mali íst' na sever a dvaja na juh. Tí, čo šli na sever, obstáli vo svojej úlohe vynikajúco, ale tí, čo šli na juh, prespali po výdatných raňajkách v tieni prvého stromu po ceste väčšiu čast' dňa a stihli prejst' len nepatrnú čast' kraja na južnom brehu Hrona. Bel svoje rozprávanie, v ktorom sa udalost' sprítomňuje priamo pred očami čitatel'a prostredníctvom množstva historických prézentov, uzatvára ponaučením, že tak to chodí, ked' človek zaspí príležitost'. Za zmienku určite stojí, že Bel sám v marginálii, kde obyčajne uvádza heslovité zhrnutie obsahu príslušnej pasáže, označuje udalost' slovom historia. ${ }^{24}$

Nasledujúci $\mathbb{S}$ III v stručnosti zhŕňa hory v okolí mesta, mestské budovy a ich vzhl'ad, pozornost'venuje tiež dvom kostolom v meste. Štvrtý paragraf obsahuje d'alšie rozprávanie, v ktorom podáva klúčovú udalost' v dejinách mesta. Mestské bane $\mathrm{v}$ tomto bližšie nešpecifikovanom období oplývali bohatými ložiskami zlata a mali z jeho tažby naozaj neobvykle vysoké výnosy. Bohatstvo, ktoré z nich mestu plynulo, však spôsobilo „ochabnutie vnútorných síl obyvatel'stva“ a vyústilo do morálneho úpadku, ktorý v konečnom dôsledku prosperitu Novobančanov zničil. Bel hovorí, že novobanskí meštania márnili ohromný majetok v takmer „nepretržitých orgiách“, ktoré sa neskôr začali konat aj v podzemí, v rozsiahlej umelo vyhĺbenej jaskyni jednej zo štôlní. K službe „Bakchovi a Venuši“ sa tu schádzal početný dav každého veku i pohlavia, priestorná jaskyňa vyhĺbená v jednej zo štôlní sa však pri týchto orgiách zrútila a smrt' v nej podla Bela našlo vtedy až štyristo ludí. Po zničení hriešneho davu v podzemí zlatej bane sa začali zmenšovat' aj výnosy z tažby, pretože „,̌̌ily akoby celkom vymizli“, a Novobančanom sa už nikdy nepodarilo obnovit' niekdajšiu slávu a bohatstvo mesta (Belius 1742: 215, 216).

Zvyšné udalosti, ktoré Bel do svojho výkladu dejín Novej Bane zaraduje v nasledujúcich paragrafoch, predstavujú d'alšie údery osudu, ktoré kedysi prosperujúce mesto nakoniec úplne zložili na kolená. Podiel'ali sa na tom výrazne aj osmanské vojská, ktoré otrasným spôsobom vyplienili a vypálili mesto po tom, čo utrpeli drvivú porážku v bitke pri Žarnovici (1664), a bolestivým neúspechom skončila aj snaha o obnovu tažby v zatopenej Starej šachte. Sprístupnit tažiarom ju mal tzv. Potterov ohňový stroj, ${ }^{25}$ vo svojej dobe najmodernejšie parné čerpadlo, prostredníctvom ktorého sa snažili zo šachty odčerpat' vodu nepretržitých sedem rokov.

V konečnom dôsledku sa teda dejiny Novej Bane vykresl'ujú ako séria neblahých udalostí, ku ktorým dochádza v dôsledku mravného úpadku meštanov.

24 Marginália znie „admensi oppido agri historia“, čiže „príbeh, ako mesto nadobudlo chotár“ (Belius 1742: 245).

25 Anglický inžinier a konštruktér Isaac Potter (nar. 17. februára 1690 v Chaddesley Corbett, Worcestershire, Anglicko, zomrel 18. februára 1735 vo Vindšachte pri Banskej Štiavnici) zostrojil a uviedol do prevádzky svoj ohňový stroj v Novej Bani roku 1722. 
Od smrti hriešneho davu v podzemnom priestore akoby ležala na meste kliatba, ktorá za žiadnych okolností neumožňuje návrat k niekdajšej prosperite. Bel svoje ponaučenie z tohto príbehu nemusí nikde explicitne vyjadrovat', každý čitatel'si ho l'ahko domyslí. Obe písomné zachytenia ústnych tradícií vel'mi dobre demonštrujú Belove rozprávačské kvality, a to i napriek tomu, že v druhom prípade zjavne nejde o povest' vychádzajúcu z ludovej slovesnosti. Tollius sa o žiadnej z oboch udalostí ani náznakom nezmieňuje, hoci na svojej ceste sa zastavil v Novej Bani a navštívil aj jedinú v tom čase ešte otvorenú štôlňu, ktorej výnosy už vtedy boli skutočne minimálne. Predstavený tohto banského diela, ktorý Tollia na jeho návšteve sprevádzal, uviedol ako dôvod naozaj mizivých výnosov nedostatok vody (Tollius 1700: 194). ${ }^{26}$ Vzdelaný anglický lekár Edward Brown, ktorý svoju cestu po slovenských banských mestách podnikol koncom šest'desiatych rokov 17. storočia, spomína Novú Baňu len v rámci vyratúvania siedmich banských miest Uhorska (Brown 1673: 98). ${ }^{27}$ Druhú z udalostí uvádza len Brückmann v 73. liste z ciest z roku 1733, nepodáva však udalost' tak ako Bel, teda ako príbeh pretkávaný aj veršami. Spomína iba, že na tamojších t'ažiarov dol'ahol „morbus epidemicus quidam“, teda „akási epidemická nákaza“, ktorú zoslal na nich Boh ako spravodlivý trest za to, že nevedeli, čo si počat's ohromným bohatstvom. K nemravnostiam pod zemou však podl'a neho došlo v dôsledku toho, že chorobe podlahli mnohí muži, na ich miesto museli nastúpit' ich ženy a tento pomocný pracovný oddiel sa v podzemí s ostatnými zdravými mužmi dopustil „nevýslovných činov“. Štôlňa sa na nich zrútila v dôsledku zemetrasenia a smrt' v nej našlo podl'a Brückmanna vyše sto ludí. Ovela viac pozornosti však venuje Potterovmu ohňovému stroju, ktorý v čase jeho návštevy už odčerpával podzemnú vodu zo Starej šachty, a uzatvára, že nevie, či celý tento nákladný podnik priniesol nejaké výsledky (Brückmann 1733: 7-8). ${ }^{28}$ Na podrobný technický opis Potterovho čerpadla, ktorý rozširuje o ten istý citát z Tollia, sa v súvislosti s Novou Baňou obmedzuje i vo svojom monumentálnom diele o baníctve Magnalia Dei In Locis Subterraneis Oder Unterirdische Schatz-Cammer Aller Königreiche und Länder (Brückmann 1730: 1000-1001).

\section{Etiologická povest' ako prameň (ludovej) etymológie}

Výklad o Oslianskom slúžnovskom okrese pokračuje d'alej opismi tamojších mestečiek, hradov, panstiev a ich dedín. Väčšinu z nich naplno zasiahli turecké boje, ktoré preto často tvoria jadro dôležitých udalostí, o ktorých Bel v ich prípade referuje.

26 Belv súvislosti s naozaj mizivými výnosmi novobanskej tažby v moderných časoch Tollia síce cituje, ale nepresne, pretože odkazuje na stranu 195.

27 Brown Novú Baňu zrejme navštívit' ani nemohol, pretože oblast' bola pod silným vplyvom Turkov (sám na strane 88 uvádza, že tribútnym mestečkom Turkov bola v tom čase aj Žarnovica a Turci tam často chodili) napriek tomu, že v roku 1664 tu v bitke pri Žarnovici utrpeli drvivú porážku. Kremnicu a Banskú Štiavnicu navštívil na jar roku 1669, Nová Baňa bola vtedy zrejme po tureckom plienení v úplne dezolátnom stave. 28 V čase vydania Brückmannovho listu Potterovo čerpadlo už v prevádzke nebolo, ked'že v Novej Bani pracovalo nepretržitých sedem rokov, teda do roku 1729. Podnik skončil bolestivým neúspechom a Bel vyčísluje sedemročné náklady bez akejkol'vek návratnosti na 130000 zlatých. Z toho vyplýva, že Brückmann s Belom kontakt neudržiaval, ked'̌̌e sa o výsledku podujatia nedopočul - v opačnom prípade by ho Bel určite informoval, ked'že sám do podujatia investoval, ako sa priznáva v poznámke h na strane 225 . 
12 K slovu sa však stále dostáva Tollius, z ktorého Bel opät' excerpuje znamenité pozorovania, ked' napríklad v opise Žarnovice referuje o tamojších zvláštnych výplniach okien. Podla Tollia ide o podobný spôsob ako v Taliansku, kde sa okná „zasklievajú “ papierom, lenže tu sa na okenné rámy natahujú vysušené mechúre. Bel túto informáciu uvádza na pravú mieru a hovorí, že nejde o mechúre, ale o tenšie blany z brucha alebo podbrušnice dobytka, ktoré sa odmastené a zbavené nečistôt natahujú na rámy ešte vlhké a následne sa nechajú vyschnút, čím získavajú potrebnú priehl'adnost' (Belius 1742: 230).

Vznik mestečka, o ktorom Bel hovorí, že má slovenské obyvatel'stvo a je slávne predovšetkým vynikajúcim pekárstvom, dokumentuje však prostredníctvom d'alšej povesti:

„Ked'v Banskej Štiavnici vzrástol počet Nemcov a Slováci, ktorí tam oddávna sídlili, sa začali obávat', že ich utlačia, rozhodli sa Sasov vyhnat'z mesta, aby sami mali viac priestoru na pohodlnejší život. Nemci boli spočiatku sotva ochotní pristúpit' na odchod, ked'však Slováci ešte neústupčivejšie naliehali, zbalili si svoje skromné imania, čo mali poruke, rozdelili sa do troch skupín a odišli zo Štiavnice hl'adat' nové sídla. Tí, čo vykročili z mesta prví, povedali ako ostrú výčitku Slovákom: Nájdeme my sebe chleby. Tým mysleli, že si l'ahko nájdu živobytie aj obživu, aj ked' museli pre príkoria Slovákov zo Štiavnice odíst'. Títo vyhnanci sa napokon usadili na tom mieste vo Vel'kohontianskej stolici, kde dnes stojí mestečko Sebechleby. Druhá skupina osadníkov bola ovela väčšia a vznešenejšia. Sotva vyšli z mesta, rozhodli sa na brehu rieky Hron postavit' hrad, ktorý pomenovali podla seba Saský kameñ, aby ich chránil pred krivdami Slovákov, ak by nejaké zamýšlali. Tí sa však vysmiali šialenému úsiliu Sasov a opovržlivo nazývali ich prvé sídlo Hladomor, zajatie hladu a smädu, ktoré si tí úbožiaci postavili na to, aby uväznení medzi jeho múrmi ako obyčajné zvery pomreli od hladu a smädu. Napokon tretia výprava sa usadila tam, kde dnes leží Žarnovica, na mieste výhodnom a schopnom uživit' množstvo ludí. Ked' sa tu Sasi vzmohli ako pol'nohospodári a zbohatli, vraj sa štiavnickým Slovákom často vysmievali so slovami žerieme my viac, pretože sa im tie útrapy vyhnanstva nakoniec tak dobre vyplatilo podstúpit'. Tým naznačovali, že sa im teraz žije lepšie a vo väčšej hojnosti než v Banskej Štiavnici. Preto sa neskôr začalo mestečku hovorit' Žermevice, dnes je to Žernovica a tam má pôvod aj dodnes slávne pekárstvo. Usúdil som, že túto historku netreba vynechat', pretože čitatel'ovi môže poskytnút príjemné rozptýlenie. Aj dnes má mestečko početné osadenstvo, ale tvorí ho slovenský lud, ktorý nie je taký bohatý a takmer celú jeho obživu predstavuje pekárstvo“" (Belius 1742: 229-230).

Nie je nijakým prekvapením, že Bel podopiera svoj výklad lokálnou ústnou tradíciou, ked'že to robí celkom bežne, prakticky vždy, ked'má podobnú povest' (najčastejšie ide o etiologické povesti) $\mathrm{k}$ dispozícii. ${ }^{29}$ Dôvod uvádza sám v závere

29 Povesti, ktoré akiste majú pôvod v ludovej slovesnosti, sa vyskytujú aj v opisoch iných stolíc, napríklad žartovná povest' o lubietovských vrabcoch (Bel 2017: 267) alebo etiologická povest' o vzniku numulitov a dvoch skalných sochách Pán a Pani v Liptovskej stolici pri obci Turík (Bel 2014: 261). 
odseku, ked'hovorí, že podobné príbehy poskytujú čitatel'ovi príjemné rozptýlenie a sú zaiste vítaným spestrením inak zdíhavého faktografického výkladu. Aj toto rozprávanie, podobne ako to o chotári Novej Bane, nesie všetky charakteristické žánrové znaky ludovej povesti, pre ktorú je typické, že sa ,usiluje dat' odpoved' na otázky typu prečo, ako a kedy niečo vzniklo, príp. zaniklo, ako sa začalo používat', alebo dalo podnet na l'udové príslovie, prezývku, ustálené spojenie a pod. V zmysle týchto žánrových zásad povesti poukazujú na vznik obce, na pôvod názvu chotárnej časti atd.“" (Melicher 1989: 181). Ani jedna z oboch povestí sa však v zbierke Tekovské povesti, z ktorej uvedený citát pochádza, nenachádza, s najväčšou pravdepodobnost'ou preto, že jej autor Jozef Melicher v nej spracoval ludové rozprávania len z kraja v bezprostrednom okolí Levíc.

Prekvapujúci je skôr fakt, že Bel sa ani nezamýšl'a nad inou etymologizáciou názvu mestečka Žarnovica, ktorá sa ponúka celkom prirodzene a bola by vel'mi l'ahko zdôvodnitel'ná. Je ním, samozrejme, pôvod v slovenskom slove „žarnov“, ktoré označuje mlynský kameň a v minulosti malo aj podobu ,žernov“. Bel sám v d'alšom výklade o mestečku pripomína, že v jeho chotári sa rodí vel'ké množstvo vynikajúceho obilia, že obyvatelia dokonca skupujú obilie aj odinakial' a melú ho na kvalitnú múku, z ktorej pečú svoj slávny chlieb (Belius 1742: 230). Pokial' ide o mestečko Sebechleby, tú istú povest' reprodukuje aj na príslušnom mieste výkladu o Hontianskej stolici, Žarnovicu a Ladomer (Šášov) už z nej však vynecháva (Belius 1742: 691). Podobne zarážajúcim prípadom je etymologizácia mena Kremnica, ktorému Bel síce priznáva slovenský pôvod, ale odvodzuje jej názov od slova „krámce“, hoci ho môže ovel'a l'ahšie odvodit' od slovenského slova „kremeň“. ${ }^{30}$ Kým etymológiu Žarnovice netreba brat' celkom vážne, skôr len ako zábavnú súčast' l'udovej povesti o vzniku mestečka, v prípade Kremnice Bel svoju etymológiu určite myslí vážne, ked'že ňou podopiera svoj historický výklad prvopočiatkov mesta, ktoré malo vzniknút z chatiek (t. j. krámcov) prvých baníkov rozptýlených v týchto miestach (Belius 1742: 182).

\section{Vedomosti o Tekovskej stolici ako chorografia}

Z uvedeného zhrnutia najdôležitejších tém, ktorých sa Bel vo svojom výklade o Tekove dotkol, vyplýva, že jeho zámerom bolo prezentovat' Tekov ako región, ktorý sa významnou mierou podiel'a na tvorbe národnej kultúrnej identity a histórie Uhorského král'ovstva. Tekov k nej prispieva nielen prastarým zvykom vítat' príchodzích pri vstupe do domu chlebom, cesnakom a cibul'ou, ale aj kremnickým zlatom a mincovňou, ktorej mince sú svetoznáme, v neposlednom rade tiež vojenskou slávou, ktorú regiónu prinieslo znamenité vít'azstvo cisárskych vojsk nad Osmanmi v bitke pri Žarnovici a neskôr v tom istom roku aj v bitke pri Leviciach. Tekov tak zohral klúčovú úlohu pri zastavení osmanskej expanzie d'alej na sever a pričinil sa o obrat vo vojne. Zaiste, vojenská história, ku ktorej má Bel čo povedat' aj z vlastnej skúsenosti, a to predovšetkým pokial'ide o posledné 

vo výklade o Tekove a je jednou z dôležitejších tém. Treba však podotknút', že stav vedeckého poznania a spracovania hlavných zdrojov, z ktorých Bel spracoval turecké vojny a ktoré otvorene priznáva, je v modernej slovenskej historiografii, ale tiež vo filológii žalostný. To platí pre Mikuláša Ištvánfiho, ${ }^{31}$ Františka Wagnera $^{32}$ a aj Františka Kaziho. ${ }^{33}$

Bel prináša množstvo zaujímavého materiálu aj pre slavistiku, národopis a folkloristiku a v jeho práci možno zaiste vybadat' zrejmú zál'ubu v zberatel'stve ludových povestí. Práve v prípade reprodukovania rôznych miestnych tradícií sa prejavuje ako vynikajúci rozprávač, ktorý dokáže nielen pútavo a zábavne prerozprávat' l'udovú povest', ale ju aj vhodne zasadit' do kontextu svojho historiografického výkladu. Ako primárny ciel' jeho výkladu sa tak javí úsilie poskytnút' komplexný obraz určitého miesta, v ktorého výslednej kompozícii dostáva priestor vel'ké množstvo rôznorodých informácií nielen z histórie, ale aj z prírodovedy, zo starožitností a z archeológie, z folkóru či jednoducho takisto to, čo sa Bel „dopočul od ktoréhosi zo svojich priatel'ov“. Tento fakt umožňuje

31 Dielo uhorského vicepalatína, dvorského kancelára a humanistického historika Mikuláša Ištvánfiho (1538-1615) Historiarum de rebus Ungaricis Libri XXXIV (NICOLAI ISTHVANFI PANNONI Historiarum de rebus Ungaricis Libri XXXIV. Coloniae Agrippinae: sumptibus Antonii Hierati, Anno MDCXXII) je zdrojom informácií pre skoršiu fázu tureckých bojov. Bel obyčajne cituje prvé úplné vydanie z roku 1622, ktoré vyšlo v Kolíne nad Rýnom sedem rokov po autorovej smrti. Ištvánfiho dejiny tvorí tridsatštyri kníh, výklad nadväzuje na Bonfiniho a dokumentuje uhorské dejiny až po rok 1606. Okrem toho, že Ištvánfi bol všestranne vzdelaný, ovládal latinčinu, gréčtinu a „takmer všetky európske jazyky“ a zastával dôležité úradné posty takmer šest'desiat rokov, bol aj vynikajúcim vojakom, osobne sa zúčastnil množstva výprav a vojenských t'ažení, cisár Rudolf II. ho prizýval k najzávažnejším rokovaniam a vo vojenskej službe zotrval aktívny až do svojho najvyššieho veku. Za obrovskú devízu diela sa už v čase jeho vydania považovalo, že Ištvánfi opisuje udalosti, ktorých bol priamym svedkom a často aj aktérom, čo si iste dobre uvedomoval aj Bel. Za zmienku stojí, že po Ištvánfiho smrti sa o vydanie jeho diela postaral kardinál Peter Pázmaň, ktorý „s maximálnou starostlivostlivost'ou Ištvánfiho spisy zozbieral, s ohromnou presnostou a nadmieru dôkladne prepísal a poslal ich pripravené do tlače" kolínskemu vydavatel'ovi Antonovi Hieratovi roku 1620, ako informuje sám Hieratus vo svojom predhovore k dielu.

32 Ide o hlavný zdroj pre neskoršiu fázu tureckých bojov, Wagnerov výklad sa však, samozrejme, dotýka aj stavovských povstaní a Bel na mnohých miestach z neho čerpá informácie aj o nich. František Wagner SJ (1675 - 1738) bol cisársky historiograf pôvodom zo švábskeho mesta Wangen i. Allgäu, autor dvoch historických prác, dvojzväzkového diela Historia Leopoldi magni Romani imperatoris I (Viedeň 1719) a II (Viedeň 1731) a Historia Josephi I Caesaris aug. felicis cum appendice usque ad pacem Badensem, ktoré vyšlo tiež vo Viedni po autorovej smrti roku 1746. Ako cisársky historik mal prístup k oficiálnym archívnym zdrojom, ktoré iní súvekí autori nemali k dispozícii, jeho práce preto obsahujú cenné materiály a informácie, ktoré sa inde nezachovali, na druhej strane je však práve preto jeho výklad na mnohých miestach značne tendenčný (Baumann 1896). Porovnaj aj Sipekiová $2019 \mathrm{~b}$.

33 František Kazi SJ (7. apríl 1695 Levice - 11. jún 1760 Bratislava), vzdelaný jezuita, profesor historickej Trnavskej univerzity (1635 - 1777), kde vyučoval najprv rétoriku, potom logiku a prírodovedu a napokon kazuistiku. Neskôr sa stal rektorom Pázmaňovho kolégia vo Viedni, Všeobecného kňazského kolégia v Trnave (Collegium generale cleri regni Hungariae), nazývaného tiež Rubrorum. Písal poéziu aj prózu, predovšetkým historiografickú. Je autorom vel'kého množstva diel, jeho najdôležitejšie historiografické práce sú trojzväzková Historia regni Hungariae (Tyrnaviae 1737 - 1749), ktorej prvý zväzok zachytáva udalosti rokov 1600 - 1637, druhý 1637 - 1663 a tretí $1664-1681$. Kazi v nej nadväzuje na nedokončené dielo Mikuláša Ištvánfiho. Druhou dôležitou historickou prácou je Historia Universitatis Tyrnaviensis Societatis Jesu (ab anno 1534) ad annum 1735 ejusdem saecularem producta (Tyrnaviae 1735), ktorá je skutočnou chválorečou na Jezuitský rád vo forme dejín Trnavskej univerzity (Wurzbach 1864: 115). Pozri tiež Sipekiová 2019a. 
Belove Vedomosti žánrovo zaradit' ako chorografiu, ktorej ciel'om je práve takáto reprezentácia určitého miesta. ${ }^{34}$

Vhistoricko-poetologickom kontexte daného žánru sa ukazuje, že Belova pozícia bola porovnatel'ná s dobovými európskymi trendmi. Spomedzi anglických a škótskych autorov 17. a 18. storočia, ktorí síce o sebe nehovoria ako o chorografoch, ale venujú sa štúdiu „starožitností, predstavuje najzaujímavejšiu paralelu k Belovi sir Robert Sibbald (1641 - 1722), vzdelaný škótsky lekár a prírodovedec. Jeho rozsiahla chorografia Škótska, z ktorej autor vydal len niekol'ko častí, sa mala volat' Atlas Scoticus seu descriptio Scotiae antiquae et modernae. Sibbald sa pri zhromažd'ovaní informácií o jednotlivých krajoch, mestách, mestečkách a dedinách, významných rodoch či pamätihodnostiach, hradoch a architektonických dominantách opieral o siet' spolupracovníkov, ktorí pre neho vyplňovali podrobný a rozsiahly dotazník. Rovnakú metódu uplatnil aj Bel, ktorý mal v každej zo stolíc spolupracovníkov (často svojich bývalých žiakov a študentov) a tí mu rovnako odovzdávali informácie o príslušnej stolici formou vyplnených dotazníkov. Stojí za povšimnutie, že pôvodný Belov zámer bol opísat' staré aj nové Uhorsko, ako ukazuje Prodromus. Pokial'ide o všeobecnú charakteristiku chorografie, asi najdôležitejším momentom je spojenie prírodovednej a spoločenskovednej časti s historiografickou čast'ou, čo, ako je zrejmé, umožňuje v konečnom dôsledku zahrnút' do výkladu výsledky naozaj najrôznejších oblastí bádania. V neposlednom rade sa náležitý dôraz kladie tiež na obrazovú reprezentáciu miesta-dôležitou a neodmyslitel'nou súčast'ou chorografie je preto aj mapa alebo iné vyobrazenia konkrétnych miest, čo vysvetluje, prečo Bel považuje za nevyhnutné čitatel'a v predhovore $A d$ lectorem (\$ XIII) ubezpečit', že aj pre štvrtý zväzok pripravil najmodernejšie mapy a rytiny miest a niekol'kých hradov Samuel Mikovíny. ${ }^{35}$

Treba tiež povedat', že chorografia mala v 17. a 18. storočí celkom bežne formu cestopisu, v ktorom autor vystupuje ako vzdelaný a dobre informovaný sprievodca pochádzajúci z domáceho prostredia.

Vysoké nároky, ktoré Bel zjavne kládol na estetickú kvalitu textu, môžu byt' v konečnom dôsledku tiež jedným z dôvodov, prečo je popri Belovi sprievodcom čitatel'a na poznávacej ceste Tekovom radšej o čosi starší, ale učený a vtipný Tollius, a nie napríklad možno odbornejší a novší, ale o to suchopárnejší Brückmann. Je málo pravdepodobné, že by Bel nepoznal Brückmannovo dielo, ked'že sa nepochybne stretli osobne a bol to práve on, kto Brückmannovi sprostredkoval cestu po slovenských banských mestách (Hronček 2019: 25). Belova poznámka v opise potnej jaskyne kúpel'ov v Sklenom, že „vzhl'ad potnej jaskyne a kúpel'ov je

34 Pre synoptické spracovanie dejín žánru a jeho základných a najdôležitejších charakteristík pozri Rohl 2012: 19-32. Hlavné charakteristiky a metódy chorografie uvádza na strane 24-29. Rohl zdôrazňuje značnú rôznorodost' podôb, ktoré chorografia môže mat', ked'že zobrazenie, resp. opis miesta sa obyčajne pokúša zahrnút vel'ké množstvo dostupných informácií o ňom alebo, pokial'možno, všetky. Napriek tejto -jeho slovami ,prokrustovskej“-povahe chorografie sa mu však darí vel'mi dobre zmapovat' dejiny žánru, ktoré dokumentuje prácami mnohých starovekých (Hérodotos, Plínius Starší, Ptolemaios alebo Strabón, ktorý sám svoju prácu nazýva chorografiou), predovšetkým však renesančných a barokových autorov. 35 K Belovým dotazníkom a spolupracovníkom pozri najnovšie Kianička 2018: 29-30. K spolupracovníkom, dotazníkom a tiež k Mikovíniho úlohe Kollárová 2006: 29-30. 
už ovel'a vznešenejší, než bol za Tolliových čias" (Belius 1742: 165), môže nepriamo odkazovat' práve na Brückmannov opis. Ten vyšiel v roku 1738, ${ }^{36}$ zachytával však pochopitel'ne stav z roku 1724, ked'Brückmann svoju cestu po Slovensku podnikol, teda len o rok neskôr ako vyšiel Prodromus. Preto zrejme pre Bela nepredstavoval ovel'a aktuálnejší opis, ktorý by bolo nevyhnutné zohl'adnit'. Zostáva doplnit', že Brückmann na danom mieste cituje aj Belov výklad v Prodrome.

Dielo Jakoba Tollia, opis jeho vlastnej cesty po slovenských banských mestách, je aj zdrojom množstva bystrých pozorovaní a unikátnych informácií, v ktorých sa Tollius dotýka najrozličnejších stránok života nielen prostého obyvatel'stva, ale prináša správy aj o strednej a urodzenejšej vrstve. Bel jeho komentáre a pozorovania na mnohých miestach dopína a aktualizuje. Vynikajúcim spôsobom tak upriamuje pozornost' čitatel'a na dielo nizozemského cestovatel'a, čím ho nielenže oživuje v uhorskom prostredí, ale rozširuje svoj vlastný výklad aj o pohl'ad na domácu kultúru zvonka. Ked'že vedomosti neboli určené len domácim čitatel'om, ale určite aj zahraničnému vzdelanému publiku, podloženie Belovho výkladu aj prostredníctvom pozorovaní zahraničného návštevníka pridalo dielu prinajmenšom na objektívnosti. Tollius predstavuje základ aj pre balneológiu, montanistiku a numizmatiku, neskrývané sú aj jeho sympatie a záujem o alchýmiu a Bel neváha jeho narážky na niektoré alchymistické diela rozsiahlo komentovat', dokonca odcitovat' príslušné miesta, na ktoré Tollius naráža. ${ }^{37}$ Bel práve vd'aka schopnosti zapracovat' na vhodnom mieste svojho výkladu zmienky vzdelaného cestovatel'a či iných autorov, často tiež uvedením miestnej ludovej tradície alebo toho, čo sa dozvedel od priatel'ov, spestruje prísne faktografický a metodologicky presne postupujúci výklad, odmeňuje čitatela rôznymi exkurzmi, a tak napíňa vlastnú premisu, ktorú formuloval v úvode štvrtého zväzku Ad lectorem. Podla nej sa snažil vybrat' do spracovania Tekovskej stolice nielen dôležité a užitočné informácie, ale takisto také, pri ktorých si čitatel'oddýchne a príjemne sa pobaví. ${ }^{38}$

\section{Pramene}

BEL, Matej, 2014. Liptovská stolica. Edične pripravili Jozef Kordoš a Martin Turóci. Čadca:

Kysucké múzeum.

BEL, Matej, 2017. Zvolenská stolica. Edične pripravili Martin Turóci a Imrich Nagy. Čadca:

Kysucké múzeum.

BEL, Matej, 2019. Tekovská stolica. Edične pripravil Martin Turóci, edícia latinského textu a preklad Jozef Kordoš. Čadca: Kysucké múzeum.

BELIUS, Matthias, 1723. Hungariae Antiquae et Novae Prodromus. Norimbergae: Sumtibus Petri Conradi Monath bibliopolae.

36 Pozri pozn. č. 17.

37 Ide konkrétne o prírodovedné dielo Physica subterranea z roku 1667, ktorého autorom bol lekár, polyhistor, chemik, pedagóg a filológ Johannes Joachim Becher (6. máj 1635, Speyer-október 1682, Londýn). Tollius vo svojom výklade o vitriole, ktorý videl v šachte Kribanus v Kremnici, hovorí, že Becher vo svojej Podzemnej prírodovede spomína istého mincovníka, ktorému sa podarilo alchymistickými postupmi získat' z uhorského vitriolu vel'ké množstvo zlata. Bel neváha v poznámke pod čiarou odcitovat' príslušné miesto priamo z Bechera a reprodukovat' celý príbeh, aby Tolliovu zmienku svojmu čitatel'ovi náležite vysvetlil. 38 „Id enim nobis per totum hoc opus negotii conscivimus, ne, quantum eius praestari potest, sicco pede transeamus quidquam, cuius notitiam aut necessariam utilemve, aut iucundam lectoribus futuram cum ratione opinaremur." 
BELIUS, Matthias, 1742. Notitia Hungariae novae Historico Geographica, divisa in partes quatuor, quarum prima Hungariam Cis-Danubianam, Altera Trans-Danubianam, Tertia Cis-Tibiscanam, quarta Trans-Tibiscanam, universim XLVIII. Comitatibus Designatam expromit. Tomus IV. Viennae Austriae: Typis Johannis Petri van Ghelen.

BROWN, Edward, 1673. A brief account of some travels in Hungaria, Servia, Bulgaria, Macedonia, Thessaly, Austria, Styria, Carinthia, Carniola, and Friuli: as also some observations on the gold, silver, copper, quick-silver mines, baths, and mineral waters in those parts: with the figures of some habits and remarkable places. London: printed by T. R. for Benj. Tooke.

BRÜCKMANN, Franz Ernst, 1730. Magnalia Dei In Locis Subterraneis Oder Unterirdische Schatz-Cammer Aller Königreiche und Länder, Zweiter Theil etc. WOLFFENBUTTELAE

BRÜCKMANN, Franz Ernst, 1733. Franc. Ernest. Brückmanni D. Epistola Itineraria LXXIII. sistens memorabilia Montis Regii in Hungaria etc. Wolffenbuttelae.

BRÜCKMANN, Franz Ernst, 1738. Franc. Ernest. Brückmanni D. Epistola Itineraria LXXV. sistens memorabilia cremnicensia in Hungaria etc. Wolffenbuttelae.

BRÜCKMANN, Franz Ernst, 1741. Franc. Ernest. Brückmanni D. Epistola Itineraria C. sistens Scriptores rerum Hungaricarum etc. Wolffenbuttelae.

PITISCUS, Samuel, 1719. Lexicon antiquitatum Romanarum in quo ritus et antiquitates cum Graecis ac Romanis communes, tum Romanis peculiares, sacrae et profanae, publicae et privatae, civiles ac militares exponuntur. Venetiis: ex typographia Balleoniana anno MDCCXIX

SAMMLUNG von Natur- und Medicin wie auch hierzu gehörigen Kunst-und Literatur-Geschichten, so sich An. 1725 in den 3. Sommer-Monaten in Schlesien und andern Ländern begeben. Als der drey u. dreyssigste Versuch ans Licht gestellet von Einigen Academ. Naturae Curios. in Bresslau. Sommer-Quartal, 1725. Leipzig und Budissin, Verlegts David Richter, 1727.

TOLLIUS, Jakob, 1700. JACOBI TOLLII EPISTOLAE ITINERARIAE ex auctoris schedis postumis recensitae, suppletae, digestae, annotationibus, observationibus et figuris adornatae cura et studio Henrici Christiani Henninii. Amstelaedami typis Francisci Halmae typographi sub signo Constantini Magni MDCC.

\section{Literatúra}

BAUMANN [osobné meno neuvedené], 1896. Wagner, Franz. In Allgemeine Deutsche Biographie 40, s. 491-492. Dostupné na internete: https://www.deutsche-biographie.de/ pnd134032594.html\#adbcontent

GLUCHMAN, Vasil a kol., 2017. Dejiny etického myslenia na Slovensku I. (do začiatku 19. storočia). Prešov: Filozofická fakulta Prešovskej univerzity.

HRONČEK, Pavel, 2019. Prínos Mateja Bela pre dejiny montanistiky. In BEL, Matej. Tekovská stolica. Edične pripravil Martin Turóci, edícia latinského textu a preklad Jozef Kordoš. Čadca: Kysucké múzeum, s. 20-43.

CHAMPON, Abel, 1910. Charles de La Rue. In The Catholic Encyclopedia. Vol. 9. New York: Robert Appleton Company. Dostupné na internete: http://www.newadvent.org/ cathen/09008a.htm

JURÍKOVÁ, Erika, 2016. Vel'ký zemepisno-historický projekt Mateja Bela. In BEL, Matej. Turčianska stolica. Edične pripravili Martin Turóci a Erika Juríková. Čadca: Kysucké múzeum, s. 16-32.

KARABOVÁ, Katarína, 2018. Autorské predhovory ako významný prvok kontextuality literárneho diela. In JURÍKOVÁ, Erika - SIPEKIOVÁ, Nicol, ed. Sambucus XIII. Práce z klasickej filológie, latinskej medievalistiky a neolatinistiky. Trnava: Filozofická fakulta Trnavskej univerzity, s. 106-116.

KIANIČKA, Daniel Haas, 2018. Matej Bel a Kremnica. In BEL, Matej/BELIUS, Matthias. Dejiny mesta Kremnica/Historia urbis Cremnitziensis. Edične pripravil Daniel Haas Kianička, edícia latinského textu a preklad Jozef Kordoš. Kremnica: NBS-Múzeum mincí a medailí, s. 11-48.

KOLDEWEY, Friedrich, 1894. Tollius, Jakob. In Allgemeine Deutsche Biographie 38, s. 423-427. Dostupné na internete: https://www.deutsche-biographie.de/pnd124188826. html\#adbcontent

KOLLÁROVÁ, Ivona, 2006. Matej Bel - vydavatel'. In KOLLÁROVÁ, Ivona. Vydavatelia v 18. storočí. Trilógia k dejinám typografického média. Bratislava: Veda, s. 13-56.

KORDOŠ, Jozef, 2019. Dejiny mesta ako literárna forma mravouky. In BRODŇANSKÁ, Erika - KOŽELOVÁ, Adriana, ed. Morálka v kontexte storočí. Prešov: Filozofická fakulta Prešovskej univerzity, s. 94-105.

KUCBEL'OVÁ, Jana - BRENKUS, Peter, 2018. Odetí do krásy. Bratislava: Ikar. 
LOPATKOVÁ, Zuzana, 2009. Majetkové postavenie a každodenný život predialistov v novoveku (na príklade zemianskej rodiny Ižoldovcov z Rybníka). In Zemianstvo na Slovensku vnovoveku. Zborník prác z interdisciplinárnej konferencie, ktorá sa konala 8. - 10. júna 2009 $v$ Martine. Čast' 1 . Postavenie a majetky zemianskych rodov. Martin: Slovenská národná knižnica, s. 362-374.

MELICHER, Jozef, 1989. Povest'-l'udový pohl'ad na minulost'. In MELICHER, Jozef. Tekovské povesti. Bratislava: Tatran, s. 181-182.

MEUSEL, Johann Georg, 1802. Lexikon der vom Jahr 1750 bis 1800 verstorbenen teutschen Schriftsteller. Erster Band. Leipzig: bey Gerhard Fleischer, dem jüngern.

NAGY, Imrich, 2013. Matej Bel a Vedomosti o Trenčianskej stolici. In BEL, Matej. Trenčianska stolica. Edične pripravili Martin Turóci a Imrich Nagy. Čadca: Kysucké múzeum, s. 29-46.

NAGY, Imrich, 2015. Oravská stolica vo Vedomostiach Mateja Bela. In BEL, Matej. Oravská stolica. Edične pripravili Martin Turóci a Imrich Nagy. Čadca: Kysucké múzeum, s. 39-53.

NAGY, Imrich, 2017. Belove Vedomosti o Zvolenskej stolici. In BEL, Matej. Zvolenská stolica. Edične pripravili Martin Turóci a Imrich Nagy. Čadca: Kysucké múzeum, s. 20-38.

NOSÁL'OVÁ, Viera, 1983. Slovenskýludový odev. Martin: Osveta.

OSLANSKÝ, František, 1986. Predialisti Ostrihomského arcibiskupstva na Slovensku od začiatku 16. storočia. Historický časopis, roč. 34, č. 4, s. 487-509.

ROHL, Darrell J., 2012. Chorography: History, Theory and Potential for Archaeological Research. In DUGGAN, Maria - McINTOSH, Frances - ROHL, Darrel J., ed. TRAC 2011: Proceedings of the Twenty First Annual Theoretical Roman Archaeology Conference, Newcastle 2011. Oxford: Oxbow Books, s. 19-32. Dostupné na internete: https://www.researchgate. net/publication/320362756_Chorography_History_Theory_and_Potential_for_Archaeological_Research

SCHERER, Wilhelm, 1882. KOBER, Tobias. In Allgemeine Deutsche Biographie 16, s. 359360. Dostupné na internete: https://www.deutsche-biographie.de/pnd116617837. html\#adbcontent

SIPEKIOVÁ, Nicol, 2019a. František Kazi, milovník histórie pod pal'bou kritiky. In JURÍKOVÁ, Erika, ed. Tyrnavia erudita II/Vzdelaná Trnava 2. Trnava: Mesto Trnava, s. 85-89.

SIPEKIOVÁ, Nicol, 2019b. František Wagner, muž za katedrou i v službách cisára. In JURÍKOVÁ, Erika, ed. Tyrnavia erudita II/Vzdelaná Trnava 2. Trnava: Mesto Trnava, s. 56-60.

ŠIMONČIČ, Jozef, 1998. František Ernest Brückmann a Trnava. In ŠIMONČIČ, Jozef. Mojej Trnave. K dejinám Trnavy a okolia. Trnava: B-print, s. 250-251.

TIBENSKÝ, Ján, 1984. O práci, koncepcii, štruktúre a osudoch Belových Notícií. In TIBENSKÝ, Ján. Matej Bel: doba, život, dielo. Bratislava: Veda, s. 217-227.

WURZBACH, Constantin von, 1864. Kazy, Franz. In Biographisches Lexikon des Kaiserthums Oesterreich. Band 11. Wien: aus der kaiserlich-königlichen Hof- und Staatsdruckerei, s. 115. Dostupné na internete: http://www.literature.at/viewer.alo?viewmode=fullscreen\&objid=11814

ZAUNICK, Rudolph, 1955. Brückmann, Franz Ernst. In Neue Deutsche Biographie 2, s. 655. Dostupné na internete: https://www.deutsche-biographie.de/pnd118515853.html \#ndbcontent

Mgr. Jozef Kordoš, PhD.

Katedra klasických jazykov

Filozofická fakulta Trnavskej univerzity

Hornopotočná 23

91843 Trnava

Slovenská republika

E-mail: jozef.kordos@truni.sk 